(2) Open Access Full Text Article

ORIGINAL RESEARCH

\title{
Increase in Tryptase and Its Role in the Synovial Membrane of Overweight and Obese Patients with Osteoarthritis of the Knee
}

This article was published in the following Dove Press journal: Diabetes, Metabolic Syndrome and Obesity: Targets and Therapy

\author{
Ken Takata' \\ Kentaro Uchida ${ }^{1,2}$ \\ Manabu Mukai' \\ Shotaro Takano' \\ Jun Aikawa (iD ${ }^{\prime}$ \\ Dai Iwase' \\ Hiroyuki Sekiguchi \\ Masayuki Miyagi' \\ Gen Inoue' \\ Masashi Takaso' \\ 'Department of Orthopedic Surgery, \\ Kitasato University School of Medicine, \\ Sagamihara City, Kanagawa 252-0374, \\ Japan; ${ }^{2}$ Shonan University of Medical \\ Sciences Research Institute, Chigasaki \\ City, Kanagawa 253-0083, Japan
}

\begin{abstract}
Purpose: The mechanisms governing evidence that obesity is a risk factor for osteoarthritis (OA) are not well understood. We previously reported an increase in mast cell (MC) marker expression in the osteoarthritic synovial membrane (SM) of patients with obesity. We hypothesized that an enzyme produced by MC, $\beta$-tryptase, may be increased in the SM of obese patients with knee OA and contribute to synovial inflammation. This study investigated the expression of the $\beta$-tryptase encoding gene, TPSB2, in the SM of obese patients with knee OA and $\beta$-tryptase-mediated regulation of IL-1 $\beta$ in synovial cells.

Patients and Methods: A total of 216 patients radiographically diagnosed with knee OA were grouped according to the World Health Organization's body mass index classifications: normal weight $\left(\mathrm{NW} ;<25 \mathrm{~kg} / \mathrm{m}^{2}\right.$ ), overweight (OW; $25-29.99 \mathrm{~kg} / \mathrm{m}^{2}$ ) and obese (OB; $\geq 30 \mathrm{~kg} /$ $\mathrm{m}^{2}$ ). Quantitative polymerase chain reaction was conducted to examine TPSB2 expression in the SM among the three groups. We also examined TPSB2 and ILIB expression in MC-rich (CD3-CD14-CD19-CD90-) and MC-poor (CD3+, CD14+, CD19+, or CD90+) fractions freshly isolated from synovial tissue. Further, the effect of $\beta$-tryptase on IL1B expression was investigated in cultured CD14-positive (macrophage-rich fraction) and CD14-negative (fibroblast-rich fraction) cells.
\end{abstract}

Results: There was significantly elevated TPSB2 expression in the OW and OB groups compared to the NW group. The MC-rich fraction had significantly higher levels of TPSB2, $C D 117$ and $C D 203 c$ than the MC-poor fraction. Recombinant human $\beta$-tryptase stimulated $I L 1 B$ expression in both the synovial fibroblast and macrophage fractions.

Conclusion: Obese patients with knee OA showed elevated TPSB2 expression in the SM. Tryptase may play a role in synovial inflammation in obese patients with OA.

Keywords: obese, mast cell, osteoarthritis, tryptase, synovial membrane

\section{Introduction}

Evidence from a number of studies has implicated obesity as a risk factor for osteoarthritis (OA). ${ }^{1-5}$ However, because OA presents in both weight-bearing and non-weightbearing joints of obese patients, ${ }^{6,7}$ mechanical loading may not be the only contributing factor governing the link between obesity and OA. It is likely that other factors also contribute to OA pathology; however, these mechanisms remain to be established.

Mast cells (MC) produce various inflammatory cytokines and growth factors that have been suggested to play a role in acute and chronic inflammatory processes. ${ }^{8}$ An increase in $\mathrm{MC}$ has been reported in the arthritic synovial membrane (SM) of patients with rheumatoid arthritis (RA), ${ }^{9-11} \mathrm{OA},{ }^{12-14}$ and spondyloarthritis. ${ }^{15} \mathrm{MC}$ number is
Correspondence: Kentaro Uchida Tel/Fax+8I-42-778-9217

Email kuchida@med.kitasato-u.ac.jp 
associated with the radiographic severity of OA. ${ }^{13} \mathrm{We}$ recently reported an increase in $\mathrm{MC}$ marker expression in the SM of obese patients, ${ }^{16}$ suggesting that MC may be involved in OA pathology in obese patients. However, the mechanisms by which MC are involved in OA pathology are not well understood.

Tryptases ( $\alpha$ - and $\beta$-tryptase) are one of the most abundant proteases found in MC. $\beta$-tryptase is the main type of tryptase released during $\mathrm{MC}$ degranulation and is involved in inflammatory cytokine production in inflammatory and allergic diseases. ${ }^{17}$ Higher $\beta$-tryptase levels have been observed in the synovial fluid of OA patients compared to healthy subjects. ${ }^{18}$ However, it is unclear whether $\beta$-tryptase levels are increased in obese patients with OA.

Studies have reported the involvement of $\beta$-tryptase in the production of inflammatory cytokines, including interleukin (IL)-1 $\beta$ and IL-8. ${ }^{19,20}$ For example, $\beta$-tryptase stimulates IL-1 $\beta$ expression in endothelial cells. ${ }^{19}$ Additionally, a number of studies have shown that synovial IL-1 $\beta$ contributes to OA pathology through the actions of matrix metalloprotease and pain-related molecules. ${ }^{21-25}$ IL-1 $\beta$ levels in synovial fluid correlate with radiographic OA severity. ${ }^{26}$ We hypothesized that $\beta$-tryptase levels may increase in the SM of obese patients with OA and contribute to the regulation of IL- $1 \beta$ in the synovium.

Here, we examined the expression of the gene encoding $\beta$-tryptase, TPSB2, in the SM of obese patients with knee OA and $\beta$-tryptase-mediated regulation of IL-1 $\beta$ in synovial cells.

\section{Patients and Methods}

All participants received total knee arthroplasty (TKA) at our hospital. Power analysis was performed with an alpha of 0.05 , power of 0.80 , and $\mathrm{N} 2$ (number of patients with normal weight)/N1 (number of overweight and obese patients) ratio of 0.64 using G*POWER3 to determine the optimal sample size. The analysis indicated the need for 84 patients with normal weight and 132 overweight/ obese patients for a detectable difference in TPSB2 between normal weight and overweight/obese groups. A total of 216 SM samples were extracted during TKA from the subjects, who were diagnosed with radiographic knee OA. A fraction of each SM sample was snap frozen in liquid nitrogen and stored at $-80^{\circ} \mathrm{C}$ until the RNA extraction procedure. SM samples randomly obtained from 10 patients were used to evaluate TPSB2 expression in $\mathrm{MC}$, while those from 5 patients were used to evaluate the effect of $\beta$-tryptase on $I L 1 B$ expression. The study protocol was approved by the Institutional Review Board for Clinical Research and Treatment of Kitasato University (approval number: KMEO B19-259). Written informed consent was obtained from all participants one day before surgery to participate in this study and to remove and use their SM. This study complied with the principles of the Declaration of Helsinki.

The subjects were grouped according to the World Health Organization's body mass index (BMI) classifications: normal weight ( $\mathrm{NW} ;<25 \mathrm{~kg} / \mathrm{m}^{2}$ ), overweight (OW; $\left.25-29.99 \mathrm{~kg} / \mathrm{m}^{2}\right)$ and obese $\left(\mathrm{OB} ; \geq 30 \mathrm{~kg} / \mathrm{m}^{2}\right)$. Table 1 shows the patients' clinical characteristics according to group. Quantitative PCR (qPCR) was used to examine TPSB2 expression in the SM among the three groups.

\section{Quantification of mRNA Expression by qPCR}

RNA extraction, cDNA synthesis and qPCR using the SYBR green method were performed using previously reported methods. ${ }^{11,15}$ Primer sequences are listed in Table 2. GAPDH was used to normalize gene expression. Relative expression was determined from mean values from all control samples (SM from the NW group or vehicle-treated cells in vitro).

\section{Expression of TPSB2 and ILIB in MC}

The expression of TPSB 2 and $I L 1 B$ was examined in MCrich and $\mathrm{MC}$-poor fractions of cells obtained from synovial tissue. Magnetic isolation using a CD117 or CD203c antibody failed to enrich the $\mathrm{MC}$ fraction. We therefore attempted to enrich the MC fraction using negative selection. Synovial tissue was immediately digested with $2 \mathrm{mg} / \mathrm{mL}$ type I collagenase solution at $37^{\circ} \mathrm{C}$ for $2 \mathrm{~h}$. Following collagenase digestion, the extracted cells were incubated with cell staining buffer (BioLegend, San Diego, CA) containing biotin-conjugated CD3 (Clone, OKT3; T cell marker), CD19

Table I Patients' Clinical Characteristics

\begin{tabular}{|l|l|l|l|l|}
\hline & $\begin{array}{l}\text { Normal } \\
(\mathbf{n = 8 4 )}\end{array}$ & $\begin{array}{l}\text { Overweight } \\
(\mathbf{n = 9})\end{array}$ & $\begin{array}{l}\text { Obese } \\
(\mathbf{n = 4 1 )}\end{array}$ & $\mathbf{P}$ \\
\hline Age (years) & $76.1 \pm 0.8$ & $73.1 \pm 0.8^{\mathrm{a}}$ & $69.0 \pm 1.3^{\mathrm{a}, \mathrm{b}}$ & $<0.00 \mathrm{I}$ \\
Male/Female, $\mathrm{n}$ & $14 / 70$ & $24 / 67$ & $8 / 33$ & 0.298 \\
$\mathrm{KL}(3 / 4), \mathrm{n}$ & $26 / 58$ & $28 / 63$ & $1 \mathrm{I} / 30$ & 0.907 \\
BMI $\left(\mathrm{kg} / \mathrm{m}^{2}\right)$ & $22.3 \pm 0.2$ & $27.3 \pm 0 . \mathrm{I}^{\mathrm{a}}$ & $32.8 \pm 0.3^{\mathrm{a}, \mathrm{b}}$ & $<0.00 \mathrm{I}$ \\
\hline
\end{tabular}

Notes: Values indicate mean \pm standard deviation unless otherwise indicated. ${ }^{a} \mathrm{P}<0.05$ compared with the normal group. ${ }^{\mathrm{b}} \mathrm{P}<0.05$ compared with the overweight group.

Abbreviations: KL, Kellgren and Lawrence grade; BMI, body mass index. 
Table 2 Primer Sequences

\begin{tabular}{|c|c|c|c|}
\hline Gene & Direction & Primer Sequence $\left(5^{\prime}-3^{\prime}\right)$ & Product Size (bp) \\
\hline TPSB2 & $\begin{array}{l}F \\
R\end{array}$ & $\begin{array}{l}\text { CGCAAAATACCACCTTGGCG } \\
\text { GTGCCATTCACCTTGCACAC }\end{array}$ & 138 \\
\hline$I L I B$ & $\begin{array}{l}F \\
R\end{array}$ & $\begin{array}{l}\text { GTACCTGTCCTGCGTGTTGA } \\
\text { GGGAACTGGGCAGACTCAAA }\end{array}$ & 153 \\
\hline$C D / 4$ & $\begin{array}{l}F \\
R\end{array}$ & $\begin{array}{l}\text { TCCCTCAATCTGTCGTTCGC } \\
\text { ATTCCCGTCCAGTGTCAGGT }\end{array}$ & 150 \\
\hline$C D 90$ & $\begin{array}{l}F \\
R\end{array}$ & $\begin{array}{l}\text { GACCCGTGAGACAAAGAAGC } \\
\text { CCCTCGTCCTTGCTAGTGAA }\end{array}$ & 138 \\
\hline$C D / 17$ & $\begin{array}{l}\mathrm{F} \\
\mathrm{R}\end{array}$ & $\begin{array}{l}\text { TGACTTACGACAGGCTCGTG } \\
\text { CCACTGGCAGTACAGAAGCA }\end{array}$ & 126 \\
\hline CD203c & $\begin{array}{l}F \\
R\end{array}$ & $\begin{array}{l}\text { CGACTGCACTATGCCAAGAA } \\
\text { GGTCCATGTGCCAGAAAGAT }\end{array}$ & 164 \\
\hline GAPDH & $\begin{array}{l}F \\
R\end{array}$ & $\begin{array}{l}\text { TGCCACTCAGAAGACTGTGG } \\
\text { TTCAGCTCTGGGATGACCTT }\end{array}$ & 129 \\
\hline
\end{tabular}

(Clone, HIB19; B cell marker), CD14 (Clone, M5E2; macrophage marker), and CD90 (Clone, 5E10; fibroblast marker) antibodies for 30 minutes at $4^{\circ} \mathrm{C}$. All antibodies were purchased from BioLegend and used at a dilution of 1:100. After washing twice with PBS, the cells were added to streptavidin-conjugated magnetic particles (BD Biosciences, CA, USA) and separated in a magnetic separation system (BD IMagTM cell separation system, BD Biosciences) into negative (MC-rich; CD3-CD14-CD19-CD90-) and positive (MCpoor; $\mathrm{CD} 3+, \mathrm{CD} 14+, \mathrm{CD} 19+$, or $\mathrm{CD} 90+)$ fractions. Expression of TPSB2 and IL1B in the negative (MC-rich) and positive fractions was evaluated using qPCR analysis without cell culture. To confirm successful enrichment of MC, expression of MC markers (CD117, CD203c) was also evaluated using qPCR analysis.

\section{$\beta$-Tryptase Stimulation of Synovial Fibroblasts and Macrophages}

To examine the role of $\beta$-tryptase in the synovium, synovial fibroblasts and macrophages were extracted from the SM of 5 knee OA patients. CD14-positive (macrophage-rich) and CD14-negative (fibroblast-rich) fractions were isolated using a magnetic separation system, as described elsewhere. $^{24}$ CD14-negative and CD14-positive cells were cultured for 7 days in six-well plates containing $\alpha$-MEM. To confirm the cell population in each fraction after 7 days of culture, the expression of synovial fibroblast (CD90) and macrophage markers (CD14) was evaluated using qPCR analysis. The cells were subsequently stimulated with vehicle (serum-free media) or $15 \mathrm{mU} / \mathrm{mL}$ of recombinant human $\beta$-tryptase (rh- $\beta$-tryptase; Promega, Madison, WI, USA) for 8 and 24 hours. $\beta$-tryptase concentrations were determined using methods described in a previous study. ${ }^{20}$ After stimulation, $I L 1 B$ expression was evaluated using qPCR analysis.

\section{Statistics}

Statistical analyses were conducted using SPSS 25.0. Continuous variables were analyzed using the Wilcoxon signed-rank test (two groups) and Kruskal-Wallis test (three groups), and categorical variables using the Fisher exact test. $\mathrm{P}<0.05$ indicated statistical significance.

\section{Results}

\section{Patients' Clinical Characteristics Among BMI Groups}

Patients were significantly younger in the OW and OB groups compared to the NW group (Table 1). The ratio of patients by sex (male/female) and Kellgren and Lawrence grade (3/4) was comparable among the groups $(\mathrm{P}=0.298$ and $\mathrm{P}=0.907$, respectively; Table 1$)$.

\section{Synovial TPSB2 Expression Among Obesity Groups}

TPSB2 expression in the OW and OB groups was significantly higher than in the NW group (Figure 1; $\mathrm{P}=0.039$ 


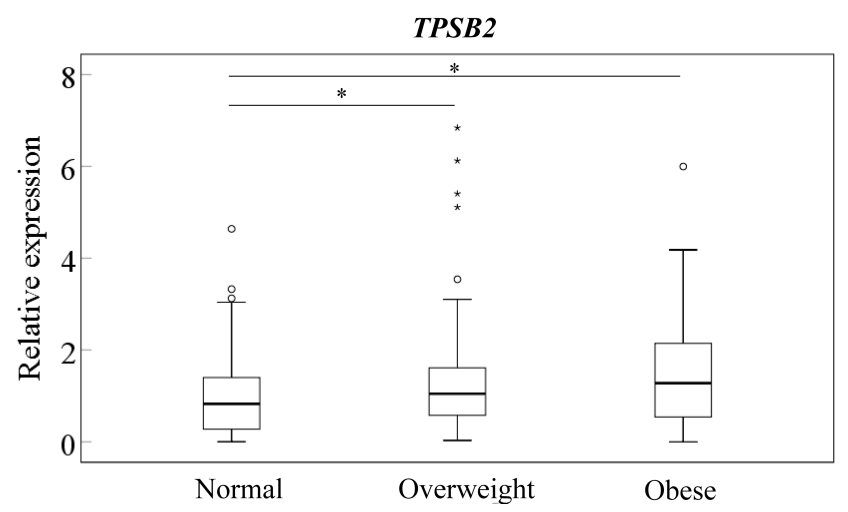

Figure I Expression of TPSB2 in the synovium of normal, overweight, and obese groups. $* \mathrm{P}<0.05$ compared to the normal groups.

and $\mathrm{P}=0.021$, respectively). No differences were observed between $\mathrm{OW}$ and $\mathrm{OB}$ groups $(\mathrm{P}=0.515)$.

\section{Expression of TPSB2 and ILIB in MC}

Expression levels of TPSB2 and $I L 1 B$ in MC were examined in MC-rich and MC-poor fractions of cells obtained
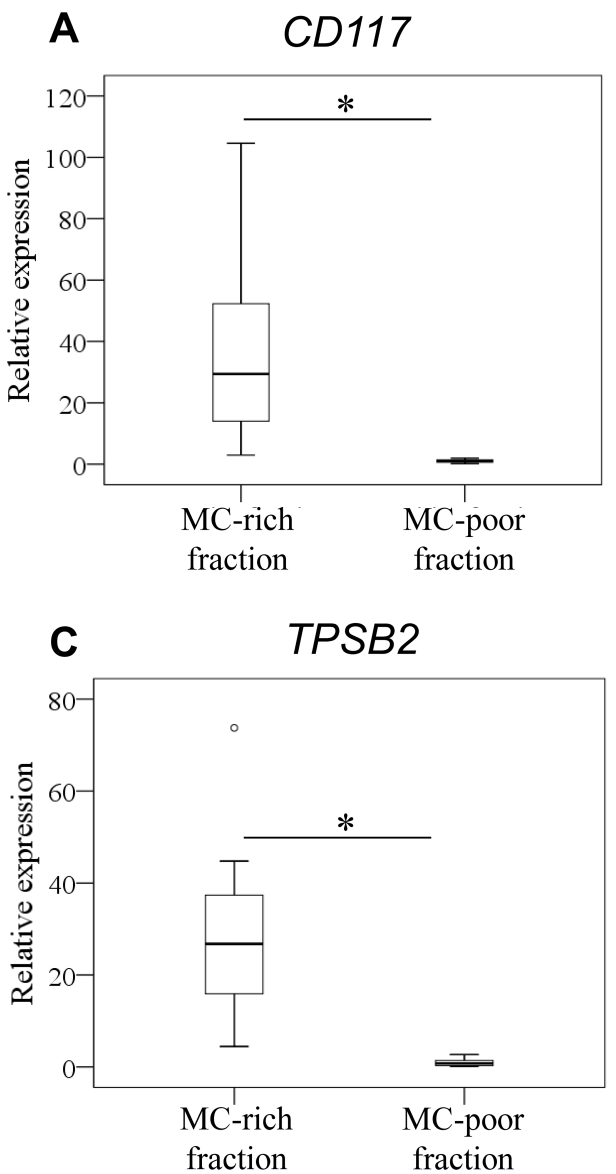

from 10 osteoarthritic SM (3 and 7 SM from normal and overweight subjects, respectively). Expression levels of CD117 and CD203 were significantly higher in the $\mathrm{MC}$-rich fraction than the MC-poor fraction (Figure 2A and $\mathrm{B}$; CD117, $\mathrm{P}=0.005 ; C D 203 c, \mathrm{P}=0.005 ;$ TPSB2, $\mathrm{P}=0.005)$. Expression levels of TPSB2 were also significantly higher in the MC-rich fraction than the MC-poor fraction (Figure $2 \mathrm{C} ; \mathrm{P}=0.005$ ). In contrast, $I L 1 B$ expression was significantly higher in the MC-poor fraction than the MC-rich fraction (Figure 2D; $\mathrm{P}=0.005$ ).

\section{Effect of $\beta$-Tryptase on IL I B Expression in Synovial Fibroblasts and Macrophages}

As mentioned above, IL1B expression was higher in the MCpoor fraction than the MC-rich fraction. Next, we examined the effect of rh- $\beta$-tryptase on $I L 1 B$ expression in synovial fibroblast- and macrophage-rich fractions obtained from 5 osteoarthritic SM (2, 2, and 1 SM from normal, overweight, and obese subjects, respectively). CD14 expression in the CD14-positive fraction was significantly higher than that in

B $\quad C D 203 c$
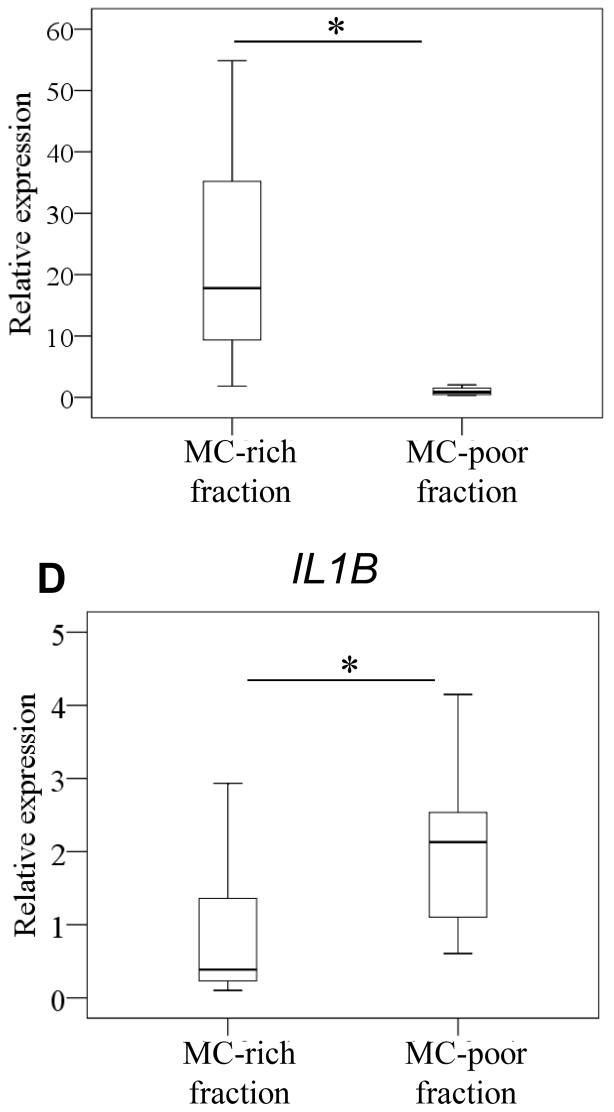

Figure 2 Expression of TPSB2 and ILIB in mast cells. Expression of CDII7 (A), CD203c (B), TPSB2 (C), and ILIB (D) in MC-rich (CD3-CDI4-CDI9-CD90-) and MC-poor $(\mathrm{CD} 3+, \mathrm{CDI} 4+, \mathrm{CDI9+}$, or $\mathrm{CD} 90+)$ fractions. $* \mathrm{P}<0.05$ compared to the MC-poor fraction. 
the CD14-negative fraction (Figure $3 \mathrm{~A} ; \mathrm{P}=0.025$ ). In contrast, CD90 expression in CD14-negative cells was significantly higher than that in CD14-positive cells (Figure 3B; $\mathrm{P}=0.001$ ). We found that rh- $\beta$-tryptase stimulated $I L 1 B$ expression in both the synovial fibroblast- and macrophage-rich fractions at $8 \mathrm{~h}$ after stimulation (Figure $3 \mathrm{C}$ and $\mathrm{D} ; \mathrm{P}=0.043$ and $\mathrm{P}=0.043$, respectively). In contrast, there was no difference in $I L 1 B$ expression at $24 \mathrm{~h}$ after stimulation in either fraction (Figure $3 \mathrm{C}$ and $\mathrm{D} ; \mathrm{P}=0.893$ and $\mathrm{P}=0.138$, respectively).

\section{Discussion}

Previous studies have reported a strong link between the development of KOA and obesity. ${ }^{1-5}$ Several studies have also reported an association between obesity and the need for TKA in OA patients. ${ }^{1,27,28}$ Coggon et al studied subjects
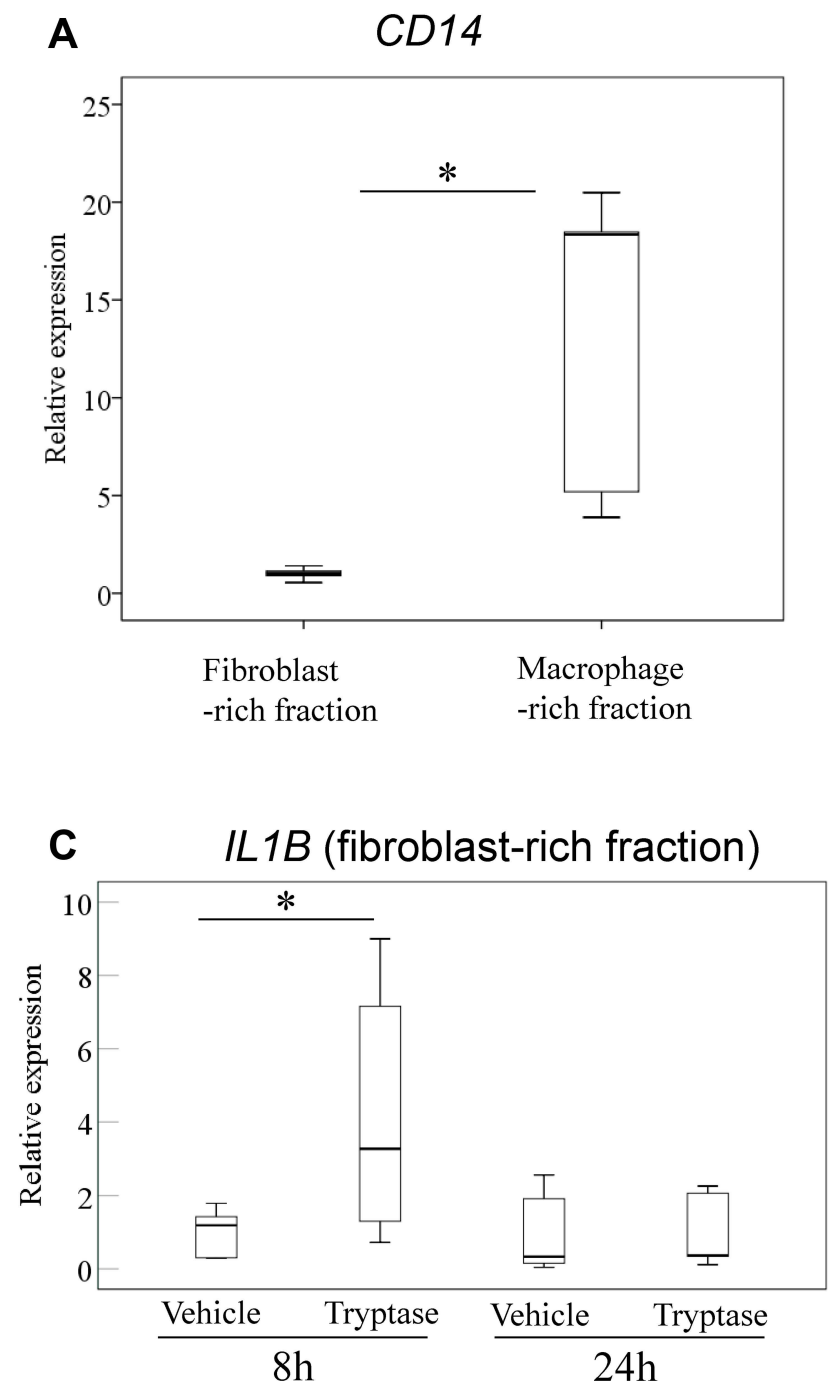

older than 45 years who had received TKA and found that the median BMI was $28.1 \mathrm{~kg} / \mathrm{m}^{2}$, or overweight. ${ }^{1}$ In our study, $61 \%$ of patients were considered overweight or obese. While approximately $70 \%$ of patients from all 3 groups had a Kellgren and Lawrence grade of 4 independent of obesity grade, patients in the $\mathrm{OW}$ and $\mathrm{OB}$ groups received TKA at a younger age than those in the NW group. Together with previous studies, our findings suggest that increasing BMI is associated with KOA progression.

Previous studies have reported elevated levels of tryptase in adipose tissue and serum from obese human subjects. ${ }^{29-31}$ BMI is significantly correlated with serum tryptase concentration and the prevalence of allergic respiratory disease symptoms. ${ }^{30}$ Circulating $\beta$-tryptase levels are correlated with BMI and the presence of carotid plaques. ${ }^{31}$ In our

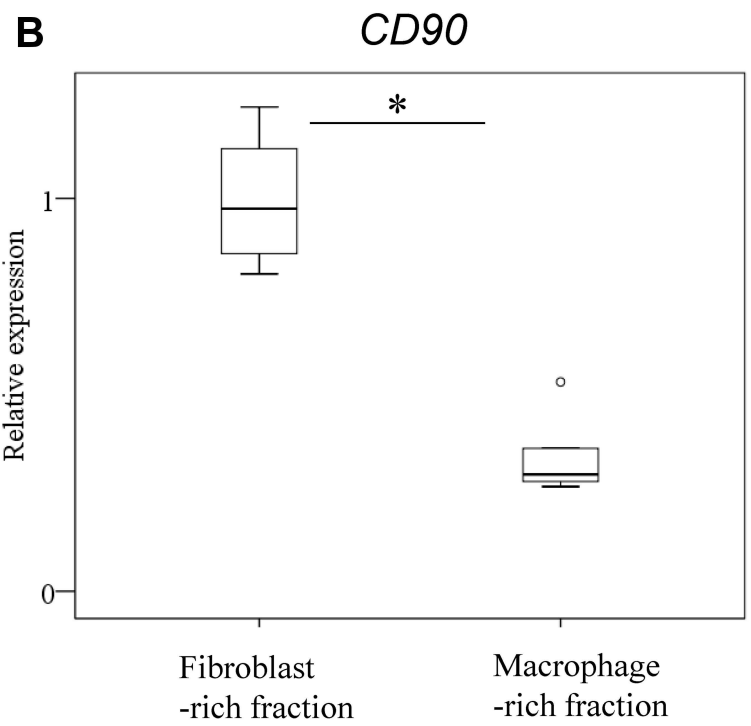

D $\quad I L 1 B$ (macrophage-rich fraction)

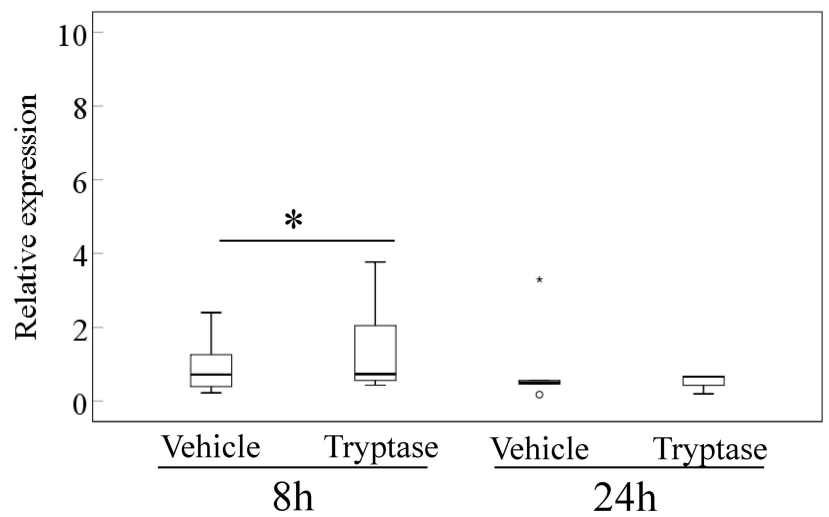

Figure 3 Effect of $\beta$-tryptase on ILIB expression in synovial fibroblasts and macrophages. Expression of CDI4 (A) and CD90 (B) in CDI4-negative (fibroblast-rich) and CDI4-positive (macrophage-rich) fractions. ${ }^{*} \mathrm{P}<0.05$ compared to the macrophage-rich fraction. Effect of $\beta$-tryptase on ILIB expression in CDI4-negative (fibroblast-rich) (C) and CDI4-positive (macrophage-rich) (D) fractions. ${ }^{*} \mathrm{P}<0.05$ compared to the vehicle-treated cells. 
study, higher TPSB2 expression levels were observed in overweight and obese subjects with $\mathrm{OA}$. In addition, higher TPSB2 expression was observed in the MC-rich fraction of cells obtained from synovial tissue. We previously reported an increase in the expression of MC markers, CD117 and $C D 203 c$, in the synovium of obese patients with OA. ${ }^{16}$ Taken together, our findings suggest that synovial tryptase levels may increase in OA patients with increasing BMI. Further, a previous study reported that the number of tryptase-positive cells is increased in the adipose tissue of obese patients. ${ }^{29}$ Synovial tissue contains an adipose tissue. Therefore, the increase in TPSB2 observed in obese and overweight patients may reflect the increase in $\mathrm{MC}$ and tryptase expression in the adipose tissue of these patients.

MC may directly and indirectly contribute to IL- $1 \beta$ production. MC have been shown to produce IL- $1 \beta^{32}$ and to interact with several other cell types including macrophages, T cells, and endothelial cells. ${ }^{33-37}$ An in vitro study showed that $\beta$-tryptase stimulates the production of IL- $1 \beta$ in endothelial cells from human umbilical veins in vitro. ${ }^{20}$ Further, MC activation induces $I L 1 B$ expression in CD68positive synovial macrophages in cultured SM cells derived from RA patients. ${ }^{36}$ In our study, $I L 1 B$ expression was significantly lower in the MC-rich fraction than in the MCpoor fraction. However, $\beta$-tryptase stimulated $I L 1 B$ expression in synovial macrophages and fibroblasts. $\beta$-tryptase may therefore indirectly contribute to synovial inflammation through activation of synovial fibroblasts and macrophages in obese patients with OA. There were several limitations in the present study. First, we did not examine protein levels. Second, we did not determine differences in TPSB2 and $I L 1 B$ expression in the MC-rich fraction among normal, overweight, and obese groups. Third, we did not determine the localization of MC in synovial membrane. Finally, the mechanism by which an increase in tryptase contributes to OA pathology remains to be determined. Histological analysis and correlation analysis between $\beta$-tryptase and inflammatory and catabolic factors are needed.

These limitations notwithstanding, we found that TPSB2 expression was elevated in the SM of obese patients with knee OA. Tryptase may therefore play a role in synovial inflammation in obese patients with OA.

\section{Acknowledgments}

This investigation was supported by a Kitasato University Research Grant for Young Researchers and Grant-in-Aid for Early-Career Scientists Grant No. 20K18073.

\section{Disclosure}

The authors report no conflicts of interest in this work.

\section{References}

1. Coggon D, Reading I, Croft P, McLaren M, Barrett D, Cooper C. Knee osteoarthritis and obesity. Int $J$ Obes Relat Metab Disord. 2001;25:622-627.

2. Felson DT. Relation of obesity and of vocational and avocational risk factors to osteoarthritis. J Rheumatol. 2005;32:1133-1135.

3. Hart DJ, Spector TD. The relationship of obesity, fat distribution and osteoarthritis in women in the general population: the Chingford Study. J Rheumatol. 1993;20:331-335.

4. Lachance L, Sowers M, Jamadar D, Jannausch M, Hochberg M, Crutchfield M. The experience of pain and emergent osteoarthritis of the knee. Osteoarthr Cartilage. 2001;9:527-532. doi:10.1053/ joca.2000.0429

5. Runhaar J, Koes BW, Clockaerts S, Bierma-Zeinstra SM. A systematic review on changed biomechanics of lower extremities in obese individuals: a possible role in development of osteoarthritis. Obes Rev. 2011;12:1071-1082. doi:10.1111/j.1467-789X.2011.00916.x

6. Grotle M, Hagen KB, Natvig B, Dahl FA, Kvien TK. Obesity and osteoarthritis in knee, hip and/or hand: an epidemiological study in the general population with 10 years follow-up. BMC Musculoskelet Disord. 2008;9:132. doi:10.1186/1471-2474-9-132

7. Oliveria SA, Felson DT, Cirillo PA, Reed JI, Walker AM. Body weight, body mass index, and incident symptomatic osteoarthritis of the hand, hip, and knee. Epidemiology. 1999;10:161-166. doi:10. 1097/00001648-199903000-00013

8. Nigrovic PA, Lee DM. Synovial mast cells: role in acute and chronic arthritis. Immunol Rev. 2007;217:19-37. doi:10.1111/j.1600-065X.20 07.00506.x

9. Ramirez J, Celis R, Usategui A, et al. Immunopathologic characterization of ultrasound-defined synovitis in rheumatoid arthritis patients in clinical remission. Arthritis Res Ther. 2016;18:74. doi:10.1186/ s13075-016-0970-9

10. Rivellese F, Mauro D, Nerviani A, et al. Mast cells in early rheumatoid arthritis associate with disease severity and support B cell autoantibody production. Ann Rheum Dis. 2018;77(12):1773-1781. doi:10.1136/annrheumdis-2018-213418

11. Rivellese F, Rossi FW, Galdiero MR, Pitzalis C, de Paulis A. Mast cells in early rheumatoid arthritis. Int J Mol Sci. 2019;20(8):2040. doi:10.3390/ijms20082040

12. Buckley MG, Gallagher PJ, Walls AF. Mast cell subpopulations in the synovial tissue of patients with osteoarthritis: selective increase in numbers of tryptase-positive, chymase-negative mast cells. J Pathol. 1998;186:67-74. doi:10.1002/(SICI)1096-9896(199809)186:1<67:: AID-PATH132>3.0.CO;2-D

13. de Lange-brokaar BJ, Kloppenburg $\mathrm{M}$, Andersen $\mathrm{SN}$, et al. Characterization of synovial mast cells in knee osteoarthritis: association with clinical parameters. Osteoarthr Cartilage. 2016;24: 664-671. doi:10.1016/j.joca.2015.11.011

14. Dean G, Hoyland JA, Denton J, Donn RP, Freemont AJ. Mast cells in the synovium and synovial fluid in osteoarthritis. $\mathrm{Br} J$ Rheumatol. 1993;32:671-675. doi:10.1093/rheumatology/32.8.671

15. Noordenbos T, Yeremenko N, Gofita I, et al. Interleukin-17-positive mast cells contribute to synovial inflammation in spondylarthritis. Arthritis Rheum. 2012;64:99-109. doi:10.1002/art.33396

16. Uchida K, Takano S, Inoue G, et al. Increase in mast cell marker expression in the synovium of obese patients with osteoarthritis of the knee. Diabetes Metab Syndr Obes. 2019;12:377-382. doi:10.2147/ DMSO.S201523

17. Caughey GH. Mast cell tryptases and chymases in inflammation and host defense. Immunol Rev. 2007;217:141-154. doi:10.1111/j.1600065X.2007.00509.x 
18. Nakano S, Mishiro T, Takahara S, et al. Distinct expression of mast cell tryptase and protease activated receptor-2 in synovia of rheumatoid arthritis and osteoarthritis. Clin Rheumatol. 2007;26:1284-1292. doi:10.1007/s10067-006-0495-8

19. Compton SJ, Cairns JA, Holgate ST, Walls AF. The role of mast cell tryptase in regulating endothelial cell proliferation, cytokine release, and adhesion molecule expression: tryptase induces expression of mRNA for IL-1 beta and IL- 8 and stimulates the selective release of IL-8 from human umbilical vein endothelial cells. J Immunol. 1998;161:1939-1946.

20. Mullan CS, Riley M, Clarke D, et al. $\beta$-Tryptase regulates IL-8 expression in airway smooth muscle cells by a PAR-2-independent mechanism. Am J Respir Cell Mol Biol. 2008;38(5):600-608. doi:10. 1165/rcmb.2007-0082OC

21. Borden P, Solymar D, Sucharczuk A, Lindman B, Cannon P, Heller RA. Cytokine control of interstitial collagenase and collagenase-3 gene expression in human chondrocytes. $J$ Biol Chem. 1996;271:23577-23581. doi:10.1074/jbc.271.38.23577

22. Lee YA, Choi HM, Lee SH, et al. Hypoxia differentially affects IL-1beta-stimulated MMP-1 and MMP-13 expression of fibroblast-like synoviocytes in an HIF-1alpha-dependent manner. Rheumatology (Oxford). 2012;51:443-450. doi:10.1093/rheumatology/ker327

23. Takano S, Uchida K, Miyagi M, et al. Nerve growth factor regulation by TNF-alpha and IL-1beta in synovial macrophages and fibroblasts in osteoarthritic mice. J Immunol Res. 2016;2016:5706359. doi:10.11 $55 / 2016 / 5706359$

24. Takano S, Uchida K, Inoue G, et al. Nerve growth factor regulation and production by macrophages in osteoarthritic synovium. Clin Exp Immunol. 2017;190:235-243. doi:10.1111/cei.13007

25. Takano S, Uchida K, Miyagi M, et al. Adrenomedullin regulates IL-1beta gene expression in F4/80+ macrophages during synovial inflammation. J Immunol Res. 2017;2017:9832430. doi:10.1155/201 $7 / 9832430$

26. Denoble AE, Huffman KM, Stabler TV, et al. Uric acid is a danger signal of increasing risk for osteoarthritis through inflammasome activation. Proc Natl Acad Sci U S A. 2011;108:2088-2093. doi:10. 1073/pnas.1012743108
27. Harms S, Larson R, Sahmoun AE, Beal JR. Obesity increases the likelihood of total joint replacement surgery among younger adults. Int Orthop. 2007;31:23-26. doi:10.1007/s00264-006-0130-y

28. Manek N, Hart D, Spector T. The association of body mass index and osteoarthritis of the knee joint. Arthritis Rheum. 2003;48:1024-1029. doi:10.1002/art.10884

29. Divoux A, Moutel S, Poitou C, et al. Mast cells in human adipose tissue: link with morbid obesity, inflammatory status, and diabetes. $J$ Clin Endocrinol Metab. 2012;97:E1677-E1685. doi:10.1210/jc.20 12-1532

30. Fenger RV, Linneberg A, Vidal C, et al. Determinants of serum tryptase in a general population: the relationship of serum tryptase to obesity and asthma. Int Arch Allergy Immunol. 2012;157:151-158. doi:10.1159/000327535

31. Moreno M, Puig J, Serrano M, et al. Circulating tryptase as a marker for subclinical atherosclerosis in obese subjects. PLoS One. 2014;9: e97014. doi:10.1371/journal.pone.0097014

32. Russi AE, Walker-Caulfield ME, Brown MA. Mast cell inflammasome activity in the meninges regulates EAE disease severity. Clin Immunol. 2018;189:14-22. doi:10.1016/j.clim.2016.04.009

33. Bhattacharyya SP, Drucker I, Reshef T, Kirshenbaum AS, Metcalfe DD, Mekori YA. Activated T lymphocytes induce degranulation and cytokine production by human mast cells following cell-tocell contact. J Leukoc Biol. 1998;63:337-341. doi:10.1002/jlb.63. 3.337

34. de Souza Junior DA, Mazucato VM, Santana AC, Oliver C, Jamur MC. Mast cells interact with endothelial cells to accelerate in vitro angiogenesis. Int J Mol Sci. 2017;18:2674.

35. Fitzgerald SM, Lee SA, Hall HK, Chi DS, Krishnaswamy G. Human lung fibroblasts express interleukin-6 in response to signaling after mast cell contact. Am J Respir Cell Mol Biol. 2004;30:585-593. doi:10.1165/rcmb.2003-0282OC

36. Sandler C, Lindstedt KA, Joutsiniemi S, et al. Selective activation of mast cells in rheumatoid synovial tissue results in production of TNF-alpha, IL-1beta and IL-1Ra. Inflamm Res. 2007;56:230-239. doi:10.1007/s00011-007-6135-1

37. $\mathrm{Xu} \mathrm{JM}$, Shi GP. Emerging role of mast cells and macrophages in cardiovascular and metabolic diseases. Endocr Rev. 2012;33:71-108. doi:10.1210/er.2011-0013

Diabetes, Metabolic Syndrome and Obesity: Targets and Therapy

Dovepress

\section{Publish your work in this journal}

Diabetes, Metabolic Syndrome and Obesity: Targets and Therapy is an international, peer-reviewed open-access journal committed to the rapid publication of the latest laboratory and clinical findings in the fields of diabetes, metabolic syndrome and obesity research. Original research, review, case reports, hypothesis formation, expert opinion and commentaries are all considered for publication. The manuscript management system is completely online and includes a very quick and fair peer-review system, which is all easy to use. Visit http://www.dovepress.com/testimonials.php to read real quotes from published authors. 